\title{
4-Aminopyridine reduces chorda tympani nerve taste responses to potassium and alkali salts in rat
}

\author{
Miwon Kim* and Charlotte M. Mistretta \\ Department of Biologic and Materials Sciences, School of Dentistry and Center for Human Growth \\ and Development, University of Michigan, Ann Arbor, MI 48109 (USA)
}

(Accepted 15 December 1992)

Key words: Taste; Potassium channel; 4-Aminopyridine; Chorda tympani nerve; Salt taste; Channel blocker

\begin{abstract}
To study the potential role of potassium channels in the taste response to potassium salts, we applied 4-aminopyridine (4-AP) to the anterior rat tongue and recorded chorda tympani nerve taste responses to chemical stimuli. 4-aminopyridine is a pharmacological blocker that reduces potassium conductance through potassium channels in nerve and muscle. Summated neural responses to stimuli dissolved in water and in 4-AP were compared. Chemical stimuli included concentration ranges of $\mathrm{KCl}, \mathrm{KBr}, \mathrm{KH}_{2} \mathrm{PO}_{4}, \mathrm{CsCl}, \mathrm{RbCl}, \mathrm{NH}{ }_{4} \mathrm{Cl}, \mathrm{NaCl}$ and sucrose. The blocker reduced chorda tympani responses to $\mathrm{KCl}$ and other potassium salts, from 0.025 to $0.25 \mathrm{M}$. Responses to ammonium, rubidium and cesium salts also were reduced, in order of effectiveness that would be predicted from known ion selectivity properties of potassium channels. Responses to $\mathrm{NaCl}$ and sucrose were not reduced. Other channel blockers, including tetraethylammonium chloride (TEA), $\mathrm{BaCl}_{2}$ and quinidine, did not reduce the response to $\mathrm{KCl}$. These are the first detailed reports of effects of potassium channel blockers on the peripheral, neural taste response. The results are consistent with a role for potassium channels in apical taste bud cell membranes in transduction for potassium salts.
\end{abstract}

\section{INTRODUCTION}

The lipid soluble quartenary ammonium compound, 4-aminopyridine (4-AP), selectively blocks or reduces potassium conductance through voltage-dependent potassium channels in squid and cockroach axons, and frog skeletal muscle ${ }^{7,21}$. Various roles for voltage-gated $\mathrm{K}^{+}$channels include termination of the action potential, repolarization, establishment of resting potential, and regulation of neurotransmitter release ${ }^{24}$. Potassium channels are ubiquitous, of diverse types, and have now been reported in all cells that display action potentials ${ }^{27}$. We hypothesized that potassium current passing through voltage-dependent channels could play a role in taste responses to potassium salts in taste bud cells. We therefore applied 4-AP to the rat tongue to learn if the pharmacological blocker altered salt responses recorded from the chorda tympani nerve.

Recent experiments indicate that potassium conductance does have a role in potassium taste reception in mammals. Based on ion transport measures across isolated rat tongue epithelium and central nervous system responses to salt stimulation of the tongue, investigators concluded that one or more potassium conductances could have a role in $\mathrm{KCl}$ taste reception ${ }^{29}$. Patch clamp recordings from isolated rat taste bud cells from fungiform papillae demonstrated that essentially all rat taste cells have outward potassium currents, blocked by tetraethylammonium chloride (TEA), barium and $4-\mathrm{AP}^{4}$. Potassium currents have also been reported in taste bud cells from rat circumvallate papilla on the posterior tongue ${ }^{1}$. In nonmammalian species, a role for voltage-dependent potassium channels in taste transduction has been suggested from experiments in mudpuppy ${ }^{17,26}$, larval tiger salaman$\operatorname{der}^{31}$, and frog ${ }^{2}$.

Reports on potassium currents and their proposed role in taste transduction conclude that there are multiple potassium conductances ${ }^{4}$; it is further suggested that the potassium taste response across a concentration range from 10 to $1,000 \mathrm{mM}$ cannot be solely explained on the basis of existing results about trans- 
port through ion channels ${ }^{29}$. The precise role of potassium channels in taste transduction is not yet understood and it is argued by some investigators that alternative mechanisms to transport of $\mathrm{K}^{+}$through potassium channels contribute to the taste response to $\mathrm{KCl}^{19,22}$.

The present state of the literature is somewhat diffuse, however, because various species are used and various taste bud populations or epithelium from differing regions of the tongue. There are not yet detailed converging data about one taste bud population from one species, derived from complementary in vivo and in vitro approaches. Thus, knowledge about salt taste reception obviously is not complete, and understanding the role of ion channels in salt taste transduction remains an important area of investigation.

We report data on rat chorda tympani nerve responses to various salts and demonstrate that 4-AP reduces responses to $\mathrm{KCl}$ and other potassium salts, but not to $\mathrm{NaCl}$ or sucrose. Responses to other alkali cations are also affected, in order of effectiveness that would be predicted from known ion selectivity properties of potassium channels. Lingual application of TEA, $\mathrm{BaCl}_{2}$, or quinidine does not reduce responses to $\mathrm{KCl}$. The results are consistent with a role for potassium channels in taste reception in rat and can be compared with published experiments on transport through rat anterior tongue epithelium ${ }^{29}$ and patch recordings from rat fungiform taste bud cells ${ }^{4}$. Preliminary reports have appeared in abstracts ${ }^{14,15}$.

\section{MATERIALS AND METHODS}

Data were collected from adult, male and female Sprague-Dawley rats (130-410 g, b.wt.). Rats were anesthetized with an intraperitoneal injection of sodium pentobarbital $(50 \mathrm{mg} / \mathrm{kg}$, b.wt.) and given additional doses as necessary. The trachea was cannulated and the animal was secured in a head holder and placed on a water-circulating heating pad. The left chorda tympani branch of the facial nerve was exposed, cut, desheathed and positioned on a platinum iridium electrode connected to an AC preamplifier, for conventional peripheral nerve recording. An indifferent electrode was positioned in nearby tissue. A mixture of Vaseline and mineral oil (1:1) was flowed around the nerve to prevent dehydration ${ }^{18}$. Neural activity was passed through an AC to DC converter ${ }^{5}$ with $0.5 \mathrm{~s}$ time constant, and displayed on a rectilinear pen recorder.

All taste stimuli were solubilized in distilled water which was also used to rinse the tongue. $\mathrm{KCl}, \mathrm{KH}_{2} \mathrm{PO}_{4}$, $\mathrm{NaCl}, \mathrm{NH}_{4} \mathrm{Cl}$ and $\mathrm{BaCl}_{2}$ were reagent grade, obtained from Baker Chemicals. $\mathrm{KBr}, \mathrm{RbCl}$, and $\mathrm{CsCl}$, and the pharmacological blockers, 4-aminopyridine, tetraethylammonium chloride, quinidine hydrochloride, and $\mathrm{Li}$ docaine (2-diethylamino- $N$-(2,6-dimethylphenyl) acetamide) were from Sigma Chemicals.

In preliminary experiments we studied effects of 0.1 to $10 \mathrm{mM} 4-\mathrm{AP}$ and found that $5 \mathrm{mM}$ was somewhat less than half maximal in effectively reducing $\mathrm{KCl}$ responses. Therefore, this concentration of blocker was used as the standard in experiments and it is well within the range of $10^{-5} \mathrm{M}$ to $10 \mathrm{mM}$ used in numerous other preparations ${ }^{8,27}$. In 30 rats we compared taste responses in the presence of water and in blocker. Taste stimuli included concentration series of $\mathrm{KCl}$, $\mathrm{NaCl}, \mathrm{NH}_{4} \mathrm{Cl}, \mathrm{KBr}, \mathrm{KH}_{2} \mathrm{PO}_{4}, \mathrm{CsCl}$, and $\mathrm{RbCl}(0.025$, $0.05,0.1,0.25,0.50$, and $0.75 \mathrm{M}$ ), and $0.5 \mathrm{M}$ sucrose. At the beginning and end of each experiment, we recorded responses to a concentration series of the respective stimulus dissolved in water. We also recorded the response to a $20 \mathrm{~s}$ application of blocker alone. Then the experimental procedure began.

Ten $\mathrm{ml}$ of stimulus dissolved in distilled water was applied to the tongue over a $30 \mathrm{~s}$ period and was followed, without rinsing, by a second application of 10 $\mathrm{ml}$ of stimulus dissolved in $5 \mathrm{mM} 4$-AP solution (Fig. 1). Thus, once the response to a given stimulus had adapted, the tongue was exposed immediately to the same stimulus with blocker. The tongue was rinsed with a continuous flow of water for $15 \mathrm{~min}$ after every application of a stimulus in 4-AP. To quantify data, a ratio was calculated of the response at $10 \mathrm{~s}$ after application of stimulus in 4-AP, divided by the response at $10 \mathrm{~s}$ after application of stimulus in $\mathrm{H}_{2} \mathrm{O}$. Measures were made at $10 \mathrm{~s}$ to evaluate blocker effects during the adapted or steady state portion of the neural response.

To control for the gradual adaptation to the stimulus that would occur even in the absence of blocker, we also made two consecutive applications of stimulus in distilled water. A ratio was calculated of the response at $10 \mathrm{~s}$ after the second stimulus application, divided by the response at $10 \mathrm{~s}$ after the first application. This 'control' or 'water' ratio was then compared to the '4-AP' or 'blocker' ratio to discern the effect of the blocker. The control stimulus applications were made before each of the experimental applications, and were always followed by a $60 \mathrm{~s}$ rinse. The entire procedure with examples of calculated ratios is illustrated in Fig. 1.

In all experiments the blocker and water control measures were made in the same animal, and repeated measures across concentrations of one stimulus were made in the same animal. For statistical analysis we 


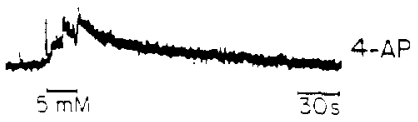

Control ratio

0.78

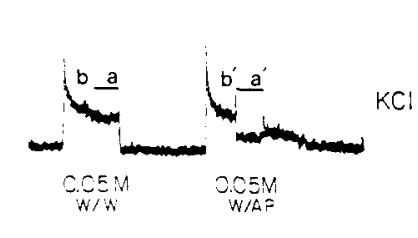

Blocker ratio

0.77

0.45

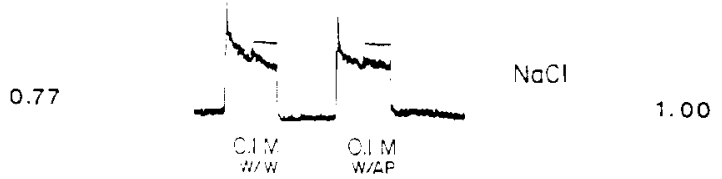

Fig. 1. Summated responses from the chorda tympani nerve, illustrating procedures to study 4-AP effects on salt taste responses. Data in the top row demonstrate the neural response to a $20 \mathrm{~s}$ application of $5 \mathrm{mM}$ 4-AP (indicated by a bar under the data), followed with a continuous water rinse. In the second row, responses are shown first to the control procedure of stimulation with $0.05 \mathrm{M} \mathrm{KCl}$ in water followed by a second stimulation of $0.05 \mathrm{KCl}$ in water without intervening rinse $(\mathrm{W} / \mathrm{W})$. Next, there is a subsequent stimulation with $0.05 \mathrm{M} \mathrm{KCl}$ dissolved in water followed by stimulation with 0.05 $\mathrm{M} \mathrm{KCl}$ dissolved in 4-AP solution, without intervening rinse (W/AP). The solid bar above summated responses indicates the duration of the second application of $\mathrm{KCl}$, either in water $(\mathrm{W} / \mathrm{W})$ or 4 -AP (W/AP). In between the control (W/W) and blocker (W/AP) procedures the tongue was rinsed with water for $60 \mathrm{~s}$. After every blocker procedure, the tongue was rinsed continuously with water for $15 \mathrm{~min}$. In the third row of data, the control and blocker procedures are illustrated for $0.1 \mathrm{M} \mathrm{KCl}$, and in the last row for $0.1 \mathrm{M} \mathrm{NaCl}$. Ratios for control and blocker procedures are presented in the margins. Ratios were calculated by dividing the response to the second stimulus application (in water for $\mathrm{W} / \mathrm{W}$, or in $4 \mathrm{AP}$ for $\mathrm{W} / \mathrm{AP}$ ) by the response to the first stimulus application (in water). For example, the control ratio of 0.78 was obtained by dividing the summated response at point 'a' by the summated response at point 'b'. Similarly, the blocker ratio of 0.22 was obtained by dividing the response measure at $a^{\prime}$ by the response at $b^{\prime}$. Whereas 4-AP reduced responses to $\mathrm{KCl}$, it seemingly enhanced the response to $\mathrm{NaCl}$.

used paired $t$-tests between responses in water and responses in blocker, for each stimulus concentration. Because we had a small number of rats in the series of studies for each chemical stimulus $(n=5$ rats per chemical), we used the Bonferroni correction to determine an acceptable $P$ value of $\leqslant 0.01$. However, we also note $P$ values $\leqslant 0.05$ in the figures.

In 22 rats we examined effects of tetraethylammonium $(1,5,10,50,500 \mathrm{mM}), \mathrm{BaCl}_{2}(1,5,50 \mathrm{mM})$, quinidine $(0.01,0.10,0.50,1.0,5.0 \mathrm{mM})$, Lidocaine $(0.10,0.10,0.50,1.0,5.0 \mathrm{mM})$, and a concentration range of 4 -AP $(0.1,1.0,3.0,5.0,10.0 \mathrm{mM})$ on responses to $\mathrm{KCl}$.

\section{RESULTS}

To study taste responses in the presence of the potassium blocker, salt stimuli were applied in solution with 4-AP. With this method effects of the blocker were reversed rapidly with water rinses, as illustrated in the neural response records for a $\mathrm{KCl}$ concentration series (Fig. 2). After block of the response to 0.025 and $0.05 \mathrm{M} \mathrm{KCl}$ with 4 -AP, neural activity was transiently increased by the water rinse.

In general, 4-AP significantly reduced responses to potassium salts, $\mathrm{CsCl}$ and $\mathrm{RbCl}$ over a range of concentrations from 0.025 to $0.1 \mathrm{M}$, but responses to concentrations at $0.25 \mathrm{M}$ and higher were not significantly reduced (Fig. 3). However, it is important to note that if a $P$ value $\leqslant 0.05$ were used to indicate
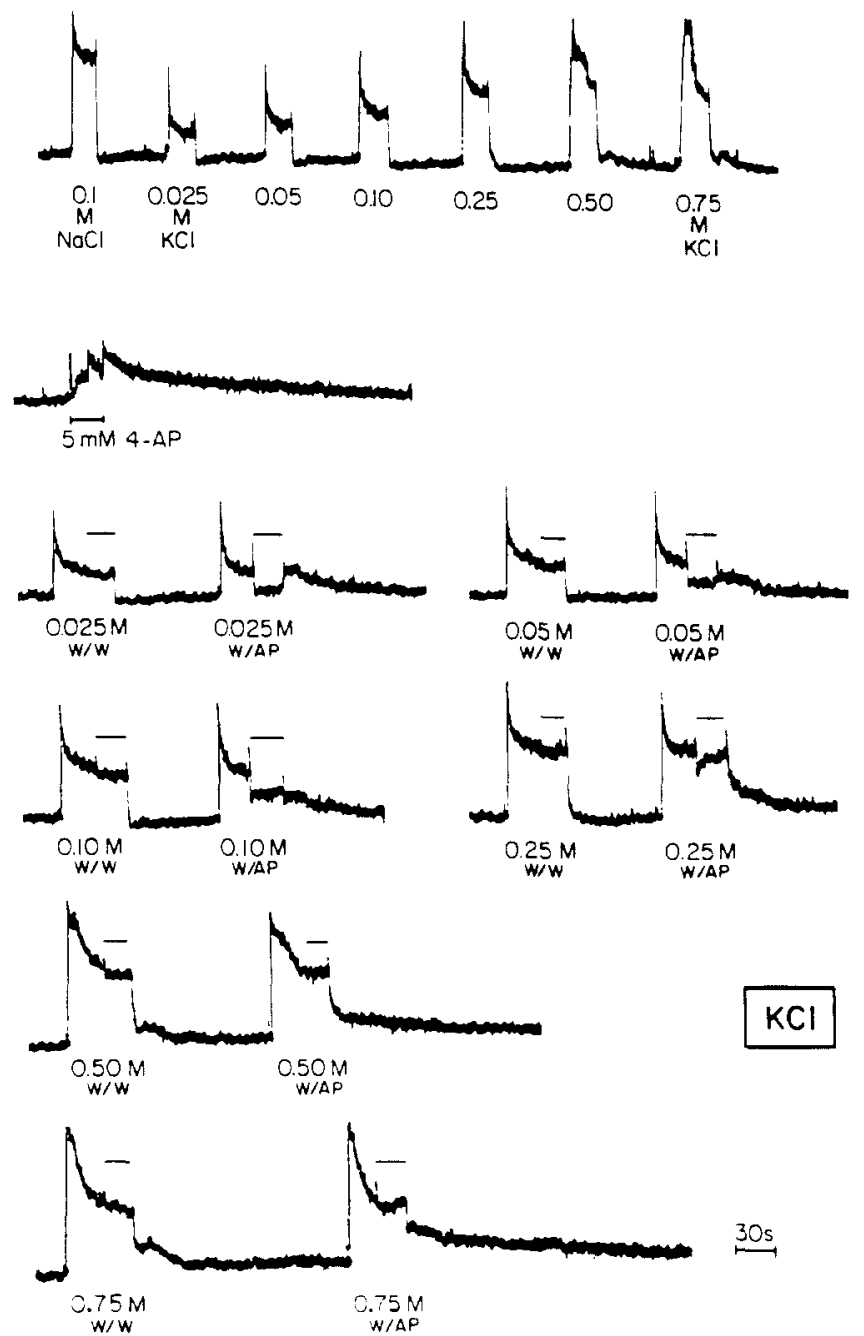

Fig. 2. Summated records from the chorda tympani nerve illustrating 4-AP effects on responses to a concentration series of $\mathrm{KCl}$. Data in the first row present responses to $\mathrm{KCl}$ in water over a concentration range from 0.025 to $0.75 \mathrm{M}$. The response to a discrete application of 4-AP in water is illustrated next, followed by records of blocker effects at ascending $\mathrm{KCl}$ concentrations. The tongue was rinsed with water for $15 \mathrm{~min}$ after any application of 4-AP. Blocker effects on $\mathrm{KCl}$ from 0.025 to $0.25 \mathrm{M}$ are apparent. 
significance, instead of the more conservative $P \leqslant 0.01$, blocker effects for the $\mathrm{K}, \mathrm{Rb}$ and $\mathrm{Cs}$ salts would be significant at $0.25 \mathrm{M}$, also (but not at 0.50 or $0.75 \mathrm{M}$ ). Inspection of the neural response records in Fig. 2 illustrates the effect of $4-\mathrm{AP}$ on $0.25 \mathrm{M} \mathrm{KCl}$, which was small, but consistently measurable. We conclude, therefore, that 4-AP has an effect on potassium, cesium and rubidium taste responses from 0.025 to 0.25 $\mathrm{M}$, with the greatest effect at lower concentrations.

The blocker effect is substantial, as indicated by the magnitude of the reduction in response ratio compared to control values. Although it appears from the ratio
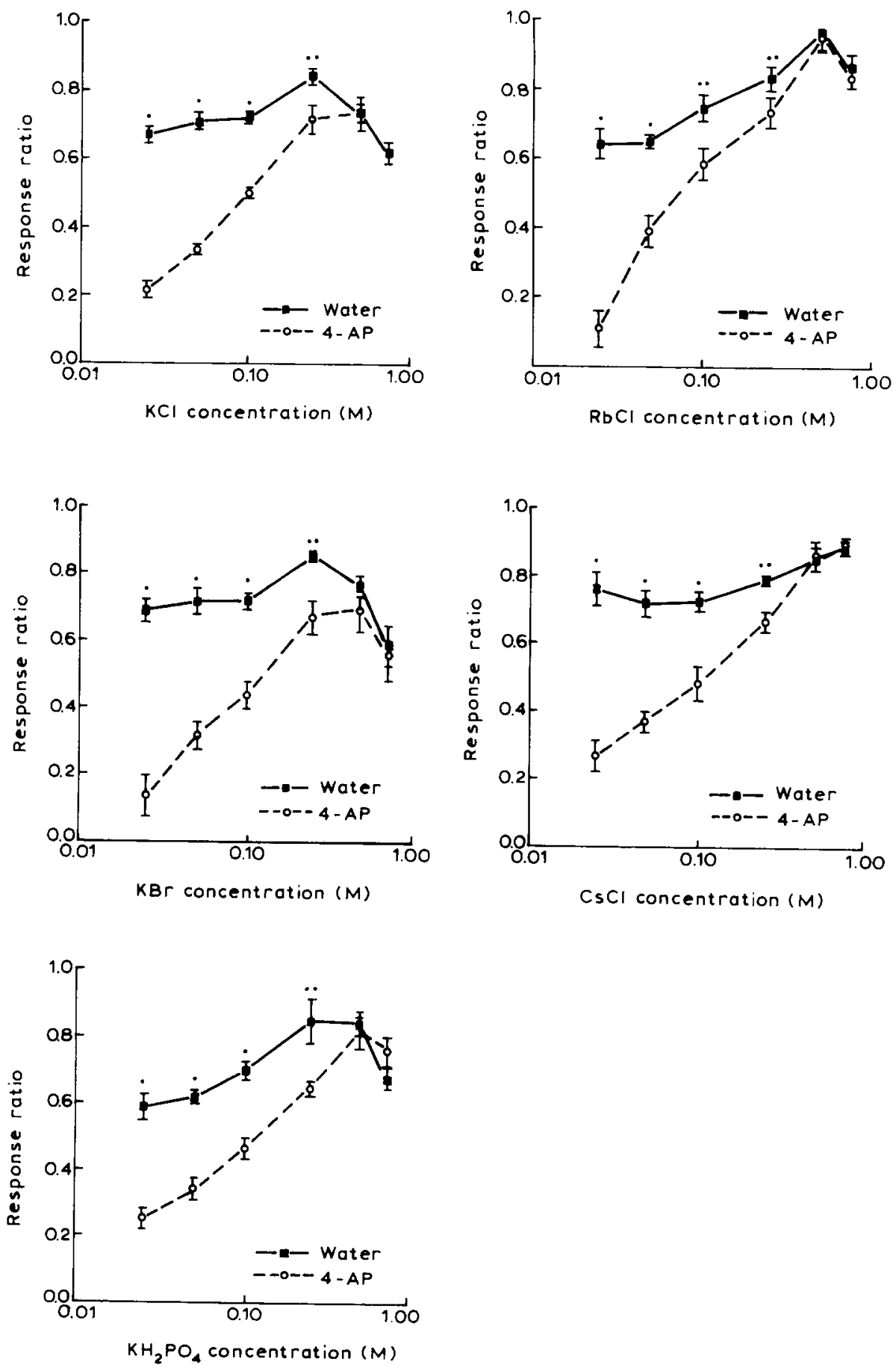

Fig. 3. Ratios of responses to concentration ranges of salts dissolved in water (solid squares), or in 4-AP (open circles). Response ratios were calculated as shown in Fig. 1. Water response ratios reflect the usual neural adaptation to salt stimulation; 4-AP response ratios reflect effects of the blocker. Data points are means, with standard error bars. At concentrations where there is a significant difference $(P \leqslant 0.01)$ between water and blocker ratios, a single dot is placed above the respective pair of points. At concentrations where the difference is significant at $P \leqslant 0.05$, two dots are placed. It is apparent that responses to potassium salts, $\mathrm{RbCl}$ and $\mathrm{CsCl}$, at concentrations from 0.025 to $0.25 \mathrm{M}$, are reduced in the presence of 4-AP. 

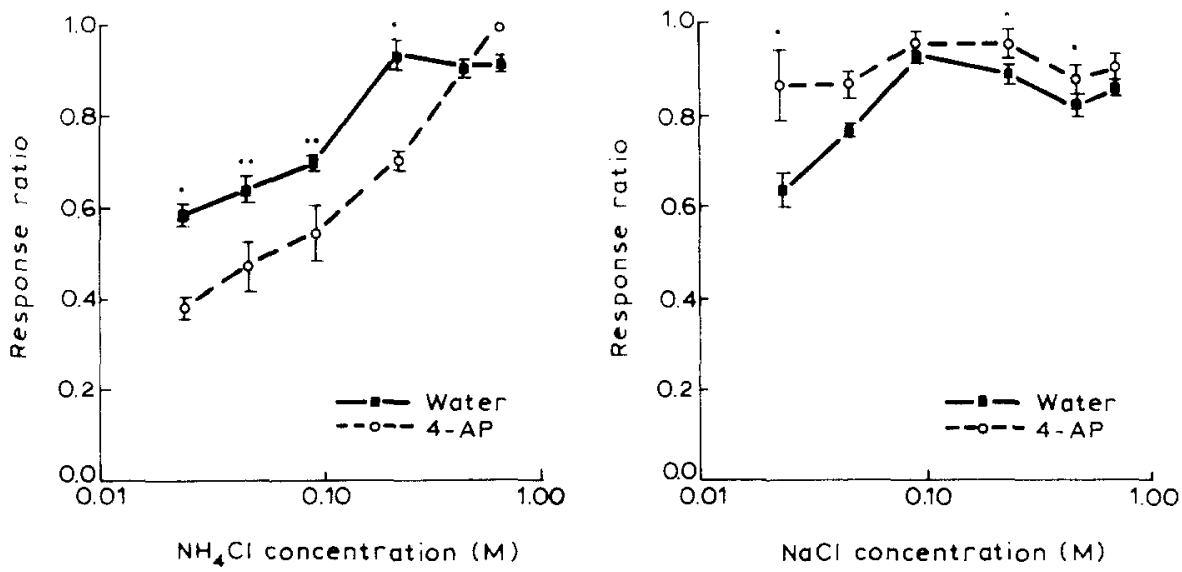

Fig. 4. Ratios of responses to concentration ranges of $\mathrm{NH}_{4} \mathrm{Cl}$ and $\mathrm{NaCl}$, dissolved in water or in 4-AP. Data points are means, with standard error bars. At concentrations where there is a significant difference between water and blocker ratios, one dot $(P \leqslant 0.01)$ or two dots $(P \leqslant 0.05)$ are placed. Responses to $\mathrm{NH}_{4} \mathrm{Cl}$ at $0.025-0.25 \mathrm{M}$ were reduced in the presence of 4-AP. Responses to $\mathrm{NaCl}$ were not reduced; in fact responses to certain concentrations were slightly increased in the presence of blocker.

measure that 4-AP does not totally block the potassium response at any stimulus concentration, inspection of the raw data in Fig. 2 illustrates that the response to $0.025 \mathrm{M} \mathrm{KCl}$ is virtually eliminated.

Responses to $\mathrm{NH}_{4} \mathrm{Cl}$ were also reduced by 4-AP (Fig. 4). The effect was significant at $P \leqslant 0.01$ for 0.025 and $0.25 \mathrm{M}$; at $P \leqslant 0.05$, there were significant effects at 0.05 and $0.10 \mathrm{M}$, also. The 4-AP effect on $\mathrm{NH}_{4} \mathrm{Cl}$ responses is of lower magnitude than the effect on potassium salts, or $\mathrm{RbCl}$ and $\mathrm{CsCl}$. In addition the 4-AP effect on $\mathrm{NH}_{4} \mathrm{Cl}$ does not appear to alter in magnitude as a function of stimulus concentration from 0.025 to $0.25 \mathrm{M}$ (Fig. 4).

Responses to $\mathrm{NaCl}$ were also altered in the presence of 4-AP but the effect was to somewhat enhance responsiveness to sodium in blocker (Fig. 4). However, the neural response records in Fig. 5 demonstrate that the enhancing effect was small when present, and perhaps the blocker prevented the gradual adaptation that occurs to $\mathrm{NaCl}$ in water.

In three rats we examined 4-AP effects on responses to $0.5 \mathrm{M}$ sucrose. No reduction or enhancement of the sucrose response was observed in the presence of blocker.

Other blockers. Concentrations of 4-AP from 1.0 to $10.0 \mathrm{mM}$ had increasing effects in blocking the response to $0.05 \mathrm{M} \mathrm{KCl} \mathrm{(Fig.} \mathrm{6).} \mathrm{There} \mathrm{was} \mathrm{no} \mathrm{measur-}$ able blocking effect at $0.1 \mathrm{mM}$ 4-AP. Over a broad concentration range, however, three other potassium blockers, TEA, $\mathrm{BaCl}_{2}$ and quinidine, did not reduce responses to $0.05 \mathrm{M} \mathrm{KCl}$ (Fig. 6). Nor did $\mathrm{BaCl}_{2}$ reduce responses to $0.025,0.1,0.25,0.5$, or $0.75 \mathrm{M} \mathrm{KCl}$. Indeed, at high concentrations of TEA and $\mathrm{BaCl}_{2}$, responses to $\mathrm{KCl}$ were augmented (Fig. 6).
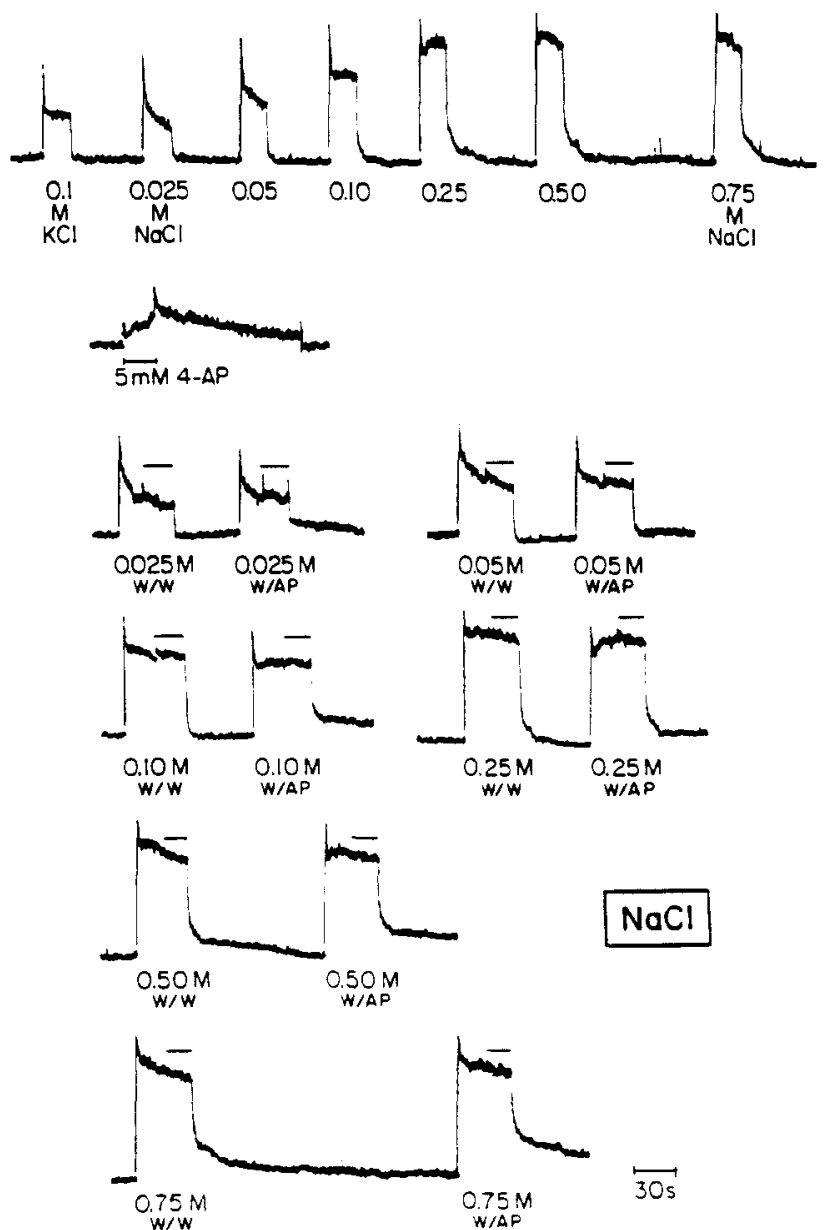

Fig. 5. Summated records from the chorda tympani nerve illustrating 4-AP effects on responses to a concentration series of $\mathrm{NaCl}$. Data in the first row are responses to $\mathrm{NaCl}$ in water, from $0.025-0.75 \mathrm{M}$. The response to a discrete application of 4-AP is illustrated next, followed by procedures to study 4-AP effects on ascending $\mathrm{NaCl}$ concentrations. The tongue was rinsed with water for $15 \mathrm{~min}$ after every application of 4-AP. The blocker does not reduce responses to $\mathrm{NaCl}$ at any concentration. At some concentrations the $\mathrm{NaCl}$ response is slightly increased in the presence of 4-AP. 
The effects of Lidocaine application on chorda tympani nerve responses were also measured (Fig. 6). Lidocaine had no effect at lower concentrations, but 10 $\mathrm{mM}$ Lidocaine reduced responses to all $\mathrm{KCl}$ concentrations from 0.025 to $0.75 \mathrm{M}$. Furthermore, at $10 \mathrm{mM}$,
Lidocaine reduced responses to $\mathrm{NaCl}$ from 0.025 to $0.75 \mathrm{M}$ (data not illustrated). In axons, local anesthetics block sodium channels and are extremely lipid soluble ${ }^{13}$, and some of these drugs also block potassium channels at high concentrations ${ }^{8}$. We assume that
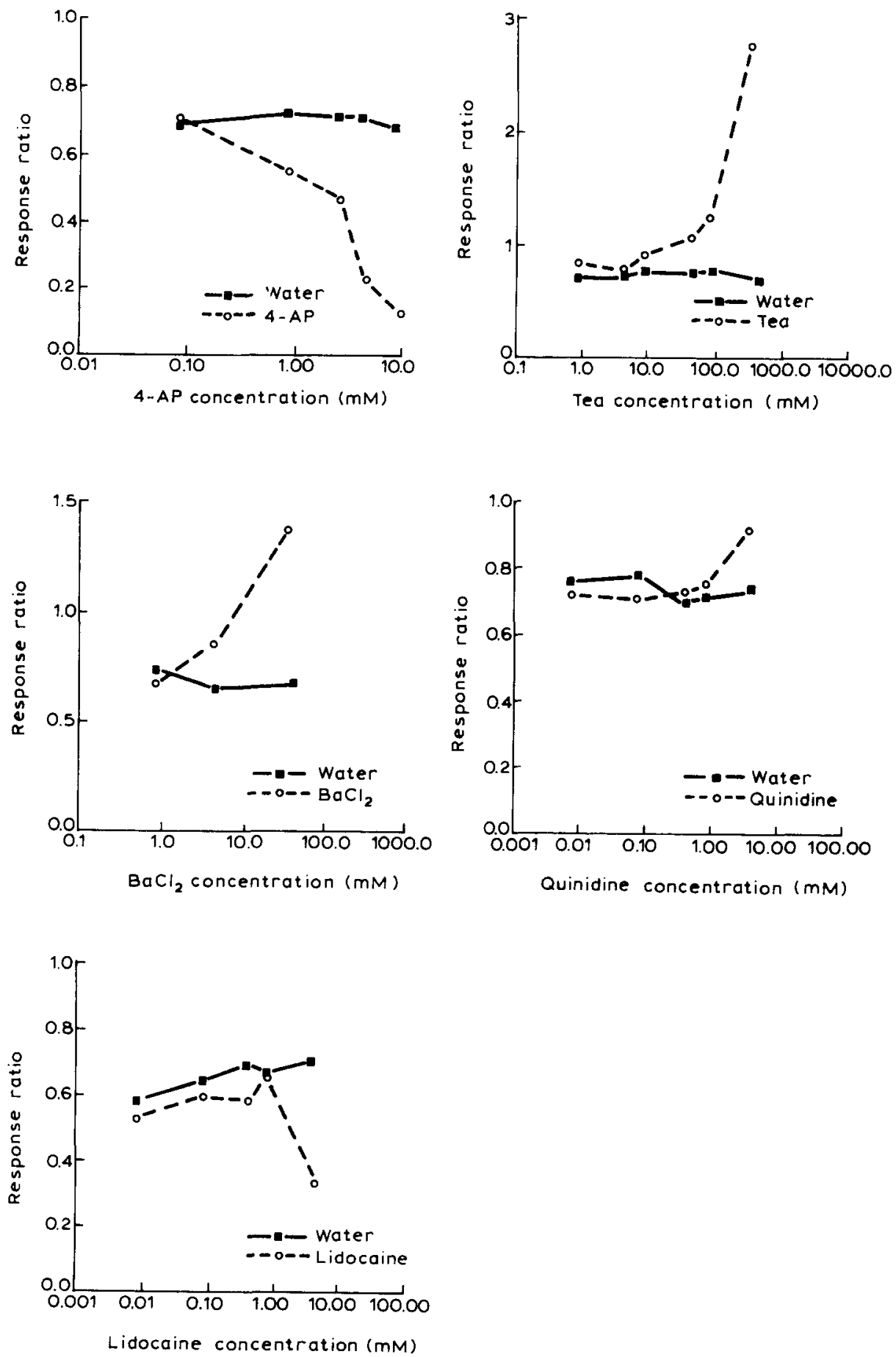

Fig. 6. Ratios of responses to $0.05 \mathrm{M} \mathrm{KCl}$, dissolved in water (solid squares) or a range of concentrations of a pharmacological blocker (open circles), as indicated for each graph. Response ratios were calculated as shown in Fig. 1. Data points are means for 2 or 3 animals. Only 4 -AP reduced responses to $\mathrm{KCl}$, and the magnitude of the effect was concentration dependent from 1.0 to $10.0 \mathrm{mM}$. High concentrations of some blockers $\left(\mathrm{TEA}, \mathrm{BaCl}_{2}\right.$ ) led to increased responses. The apparent reduction in response at the highest concentration of Lidocaine might relate to the extreme lipid solubility of this anesthetic. 


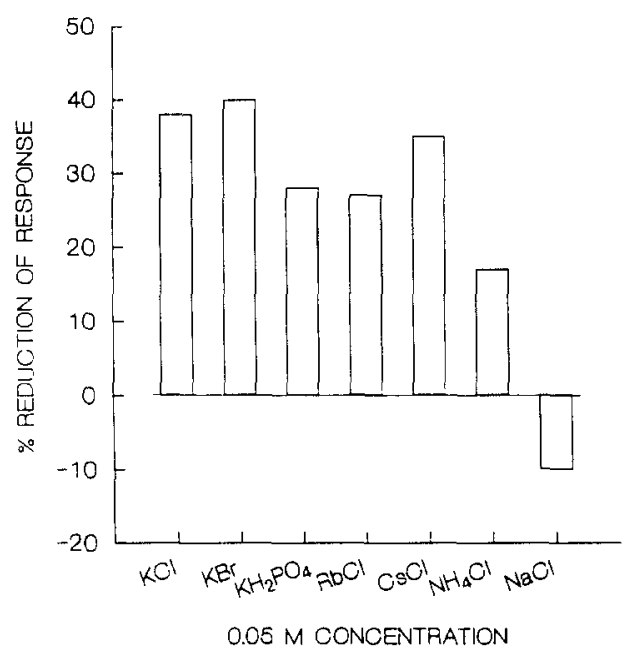

Fig. 7. Magnitude of effect of $5 \mathrm{mM}$ 4-AP on chorda tympani responses to $0.05 \mathrm{M}$ concentrations of various salts. The \% reduction is the difference between the water and 4-AP response ratios to 0.05 $\mathrm{M}$ stimulus. $\mathrm{NaCl}$ responses were not reduced by $4-\mathrm{AP}$, but slightly enhanced.

the taste response effects observed with a very high Lidocaine concentration relate to these properties.

\section{DISCUSSION}

These results demonstrate that the potassium channel blocker, 4-AP, substantially reduces chorda tympani nerve responses to potassium salts, and to $\mathrm{CsCl}$ and $\mathrm{RbCl}$. A moderate effect on $\mathrm{NH}_{4} \mathrm{Cl}$ is observed. There is no reduction of taste responses to $\mathrm{NaCl}$ or sucrose.

The order of effects on various salts at $0.05 \mathrm{M}$ concentration is presented in Fig. 7. Essentially, 4-AP reduces $\mathrm{KCl}=\mathrm{KBr}>\mathrm{CsCl}>\mathrm{KH}_{2} \mathrm{PO}_{4}=\mathrm{RbCl}>\mathrm{NH}_{4}$ $\mathrm{Cl}$. This order is similar to the general selectivity sequence for permeation of most potassium channels: $\mathrm{K}^{+}>\mathrm{Rb}^{+}>\mathrm{NH}_{4}^{+25}$. The comparatively small blocker effect on $\mathrm{NH}_{4} \mathrm{Cl}$ is consistent both with results of 4-AP in other preparations ${ }^{27}$ and with the fact that ammonium ion can pass through most potassium channels ${ }^{20}$. The permeability to $\mathrm{Na}^{+}$and $\mathrm{Li}^{+}$ions in potassium channels is usually too low to be measured, and in our neural recordings 4-AP did not reduce responses to $\mathrm{NaCl}$, but rather slightly enhanced them. Overall, the data are consonant with the proposition that potassium channels have a role in mediating the neural taste response to potassium salts. The presumed permeability to several alkali metals suggested by our data agrees with knowledge about sensory receptor channels ${ }^{13}$.

Although neurophysiological measures in vivo can only support, but not demonstrate, the hypothesis that potassium channels play a role in potassium taste transduction, such measures provide important converging data to aid in interpreting patch recordings from taste cells, or lingual epithelium transport experiments. In studies with dissociated cells and epithelia, results must be interpreted carefully due to effects of dissociation on structure and function ${ }^{3,25}$, and possible enzyme effects ${ }^{10}$. It clearly remains essential to study taste transduction at several experimental levels.

Interestingly, whole cell patch experiments on taste bud cells from rat fungiform papillae indicated that essentially all cells had outward $\mathrm{K}$ currents and that these were blocked by $10 \mathrm{mM}$ TEA, $10 \mathrm{mM}$ Ba and 5 $\mathrm{mM}$ 4-AP ${ }^{4}$. Whereas TEA reduced peak and steady currents equally, 4-AP blocked the peak current more efficiently. In our experiments, TEA, Ba and quinidine were not effective in reducing potassium responses. With the method we applied, however, the blockers had direct access to taste bud cell apices only. In the whole cell patch recordings, various membrane regions were studied. Also, from transport experiments across rat tongue epithelium containing fungiform papilla, it was concluded that $\mathrm{BaCl}_{2}$ inhibited $\mathrm{KCl}$ transport through a $\mathrm{K}^{+}$selective pathway in serosal membranes, but that 4-AP blocked transport through the mucosal or apical side ${ }^{29}$.

Others have reported that whereas intracellularly applied TEA generally blocks various voltage-activated $\mathrm{K}^{+}$channels, extracellular TEA has differing results in different preparations ${ }^{20}$. Squid axon channels are not affected even by high concentrations of TEA, but millimolar TEA concentrations block $\mathrm{K}^{+}$channels at frog node of Ranvier. Although both 4-AP and TEA reportedly block certain potassium channels when applied externally, the blockers presumably affect different sites ${ }^{11}$. 4-AP is membrane permeable, and blocks equally well from internal or external application ${ }^{27}$. TEA is not membrane permeable and blocking effects differ when the agent is applied internally or externally. Internally applied TEA is reportedly less specific in action $^{30}$.

It is well recognized that potassium currents are highly diverse, due to the presence of different types of $\mathrm{K}$ channels ${ }^{20,27}$, and various types of channel can be found in the same cell. Therefore, it is not surprising that with different species and different taste bud populations, varying effects of pharmacological blockers have been observed in the taste system.

Although evidence has accumulated across species for a role of $\mathrm{K}^{+}$channels in potassium taste reception, our experiments with the pharmacological blocker 4-AP indicate an effect on salt concentrations at or below $0.25 \mathrm{M}$ only, and the blocker does not usually eliminate the salt response. Therefore, other membrane components may exist that function in potassium taste reception and that are not sensitive to apical application of 
4-AP. These results are consistent with responses to hypo- and hyperosmotic salts recorded from the rat nucleus of the solitary tract in the presence of 4- $\mathrm{AP}^{29}$. In addition, the response to the anion portion of the salts that we used must be considered ${ }^{9,33}$ and this presumably would not be blocked by 4-AP.

Other investigators continue to emphasize the possible role of alternative mechanisms or additional mechanisms in salt taste transduction ${ }^{12,19,22,23}$. Because 4-AP and other pharmacological blockers for $\mathrm{K}^{+}$channels are characteristically unspecific with low affinities ${ }^{24}$ and can have other effects on the nervous system in addition to $\mathrm{K}^{+}$channel block ${ }^{7,8,11}$, alternative explanations for observed effects on potassium and alkali salt taste responses must be entertained.

In summary, converging reports from several laboratories suggest that ion channels have a role in gustatory responses to salt stimuli in mammals ${ }^{16,28,32}$. Our experiments on effects of several pharmacological, $\mathrm{K}^{+}$channel blockers on chorda tympani nerve responses to a range of concentrations of various potassium salts and other alkali salts, support the hypothesis that potassium channels on apical taste membranes are involved in potassium taste responses. These data from peripheral neurophysiological experiments in rat converge with results from the central taste system, from epithelial transport studies, and from whole cell patch recordings of fungiform taste cells ${ }^{4,29}$ in clarifying salt taste transduction mechanisms in rodent taste buds on the anterior tongue.

Acknowledgements. This research was partially supported by NIH Grant DC00456 to CMM. Dr. David Dawson was extremely helpful in discussing all aspects of this work while it was in progress.

\section{REFERENCES}

1 Akabas, M., Dodd, J. and Al-Awqati, Q., Identification of electrophysiologically distinct subpopulations of rat taste cells, $J$. Membrane Biol., 114 (1990) 71-78.

2 Avenet, P. and Lindemann, B., Patch-clamp study of isolated taste receptor cells of the frog, J. Membrane Biol., 97 (1987) 223-240.

3 Avenet, P. and Lindemann, B., Perspectives of taste reception, $J$. Membrane Biol., 112 (1989) 1-8.

4 Behe, P., DeSimone, J.A., Avenet, P. and Lindemann, B., Membrane currents in taste cells of the rat fungiform papilla, J. Gen. Physiol, 96 (1990) 1061-1084.

5 Beidler, L.M., Properties of chemoreceptors of tongue of rat, $J$. Neurophysiol., 16 (1953) 595-607.

6 Beidler, L.M., Anion influences on taste receptor response. In T. Hayashi (Ed.), Olfaction and Taste, II, Pergamon, Oxford, 1967, pp. 509-534.

7 Bostok, H., Sears, T.A. and Sherratt, R.M., The effects of 4aminopyridine and tetraethylammonium ions on normal and demyelinated mammalian nerve fibers, J. Physiol., 313 (1981) 301 315.

8 Cook, N.S. and Quast, U., Potassium channel pharmacology. In N.S. Cook (Ed.), Potassium Channels, Structure, Classification, Function and Therapeutic Potential, Wiley, NY, 1990, pp. 181-255.
9 Formaker, B.K. and Hill, D.L., An analysis of the residual $\mathrm{NaCl}$ response following amiloride, Am. J. Physiol, 255 (1988) R1002R1007.

$10 \mathrm{Garty}, \mathrm{H}$. and Edelman, I.S., Amiloride-sensitive trypsinization of apical sodium channels, J. Gen. Physiol, 81 (1983) 785-803.

11 Glover, W.E., The aminopyridines, Gen. Pharmacol., 13 (1982) $259-285$.

12 Heck, G.L., Persaud, K.C. and DeSimone, J.A., Direct measurement of translingual epithelial $\mathrm{NaCl}$ and $\mathrm{KCl}$ currents during the chorda tympani taste response, Biophys. J., 55 (1989) 843-857.

13 Hille, B., Ionic Channels of Excitable Membranes, Second Edn. Sinauer Assoc., Sunderland, MA, 1992.

$14 \mathrm{Kim}, \mathrm{M}$. and Mistretta, C.M., 4-Aminopyridine depresses $\mathrm{KCl}$ taste responses recorded from rat chorda tympani nerve, Neurosci. Abstr., 12 (1986) 1351.

$15 \mathrm{Kim}, \mathrm{M}$. and Mistretta, C.M., Effects of potassium channel blockers on rat chorda tympani nerve responses, Chemical Senses, 12 (1987) 671.

16 Kinnamon, S.C., Taste transduction: a diversity of mechanisms, Trends Neurol. Sci., 11 (1988) 491-496.

17 Kinnamon, S.C. and Roper, S.D., Evidence for a role of voltagesensitive apical $\mathrm{K}^{+}$channels in sour and salt taste transduction, Chemical Senses, 13 (1988) 115-121.

18 Kitada, Y., Bradley, R.M. and Mistretta, C.M., Maintenance of chorda tympani salt taste responses after nerve transection in rats, Brain Res., 302 (1984) 163-170.

19 Kurihara, K., Yoshii, K. and Kashiwayanagi, M., Review: Transduction mechanisms in chemoreception, Comp. Biochem. Physiol, 85A (1986) 1-22.

20 MacKinnon, R. and Yellen, G., Mutations affecting TEA blockade and ion permeation in voltage-activated $\mathrm{K}^{+}$channels, Science, 250 (1990) 276-279.

21 Meves, H. and Pichon, Y., The effect of internal and external 4-aminopyridine on the potassium currents in intracellularly perfused squid giant axons, J. Physiol, 268 (1977) 511-532.

22 Nakamura, M. and Kurihara, K., Non-specific inhibition by amiloride of canine chorda tympani nerve responses to various salts: do $\mathrm{Na}^{+}$-specific channels exist in canine taste receptor membranes?, Brain Res., 524 (1990) 42-48.

23 Nakamura, M. and Kurihara, K., Rat taste nerve responses to salts carrying cations of large molecular size; are the taste responses to the salts induced by cation transport across apical membranes of taste cells?, Comp. Biochem. Physiol, 100A (1991) 661-665.

$24 \mathrm{Rehm}, \mathrm{H}$. and Tempel, B.L., Voltage-gated $\mathrm{K}^{+}$channels of the mammalian brain, FASEB J., 5 (1991) 164-170.

25 Richter, H.-P., Avenet, P., Mestres, P. and Lindemann, B., Gustatory receptors and neighboring cells in the surface of an amphibian taste disc: in situ relationships and response to cell isolation, Cell Tissue Res., 254 (1988) 83-96.

26 Roper, S.D. and McBride Jr., D.W., Distribution of ion channels on taste cells and its relationship to chemosensory transduction, J. Membrane Biol., 109 (1989) 29-39.

27 Rudy, B., Diversity and ubiquity of K channels, Neuroscience, 25 (1988) $729-749$.

28 Schiffman, S.S., Taste transduction and modulation, NIPS, 3 (1988) 109-112.

29 Simon, S.A., Robb, R. and Schiffman, S.S., Transport pathways in rat lingual epithelium, Pharmacol, Biochem. Behav, 29 (1988) $257-267$.

30 Stanfield, P.R., Tetraethylammonium ions and the potassium permeability of excitable cells, Rec. Physiol. Biochem. Pharmacol., 97 (1983) 1-67.

31 Sugimoto, K. and Teeter, J.H., Voltage-dependent ionic currents in taste receptor cells of the larval tiger salamander, J. Gen. Physiol., 96 (1990) 809-834.

32 Teeter, J., Funakoshi, M., Kurihara, K., Roper, S., Sato, T. and Tonosaki, K., Generation of the taste cell potential, Chem. Senses, 12 (1987) 217-234.

33 Ye, Q., Heck, G.L. and DeSimone, J.A., The anion paradox in sodium taste reception: resolution by voltage-clamp studies, Science, 254 (1991) 724-726. 